Revision 0

\title{
512-S Facility, Actinide Removal Process \\ Radiological Design Summary Report
}

\author{
Author: S. J. Nathan
}

Date: August 2003

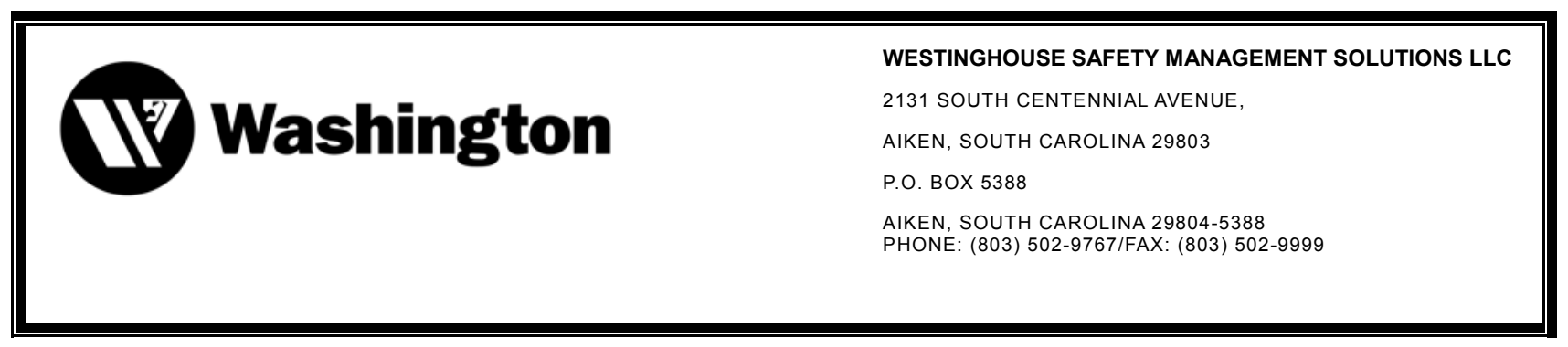


This document was prepared in conjunction with work accomplished under Contract No. DE-AC09-96SR18500 with the U. S. Department of Energy.

\section{DISCLAIMER}

This report was prepared as an account of work sponsored by an agency of the United States Government. Neither the United States Government nor any agency thereof, nor any of their employees, makes any warranty, express or implied, or assumes any legal liability or responsibility for the accuracy, completeness, or usefulness of any information, apparatus, product or process disclosed, or represents that its use would not infringe privately owned rights. Reference herein to any specific commercial product, process or service by trade name, trademark, manufacturer, or otherwise does not necessarily constitute or imply its endorsement, recommendation, or favoring by the United States Government or any agency thereof. The views and opinions of authors expressed herein do not necessarily state or reflect those of the United States Government or any agency thereof.

This report has been reproduced directly from the best available copy.

Available for sale to the public, in paper, from: U.S. Department of Commerce, National Technical Information Service, 5285 Port Royal Road, Springfield, VA 22161, phone: (800) 553-6847, fax: (703) 605-6900

email: orders@ntis.fedworld.gov

online ordering: http://www.ntis.gov/help/index.asp

Available electronically at http://www.osti.gov/bridge

Available for a processing fee to U.S. Department of Energy and its contractors, in paper, from: U.S. Department of Energy, Office of Scientific and Technical Information, P.O. Box 62, Oak Ridge, TN 37831-0062,

phone: (865)576-8401,

fax: (865)576-5728

email: $\underline{\text { reports@ adonis.osti.gov }}$ 
WSRC-TR-2003-00167

REVISION 0

This page was intentionally left blank 
WSRC-TR-2003-00167

REVISION 0

This page intentionally left blank. 


\section{TABLE OF CONTENTS}

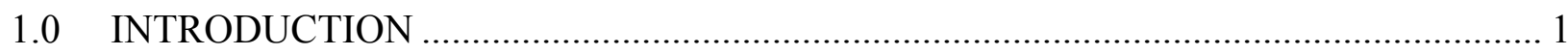

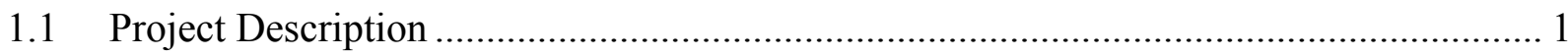

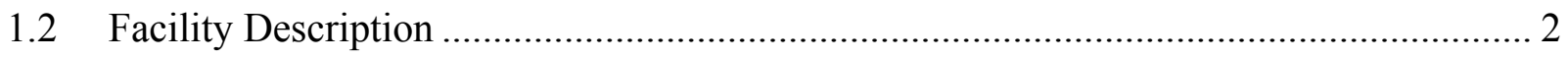

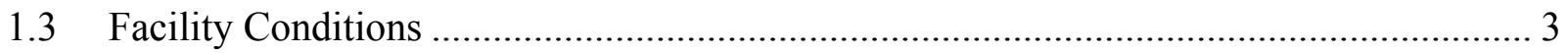

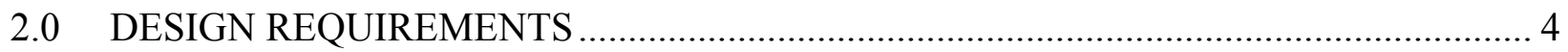

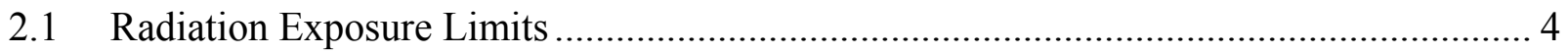

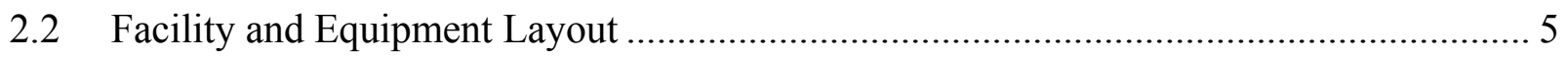

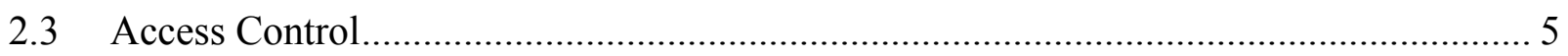

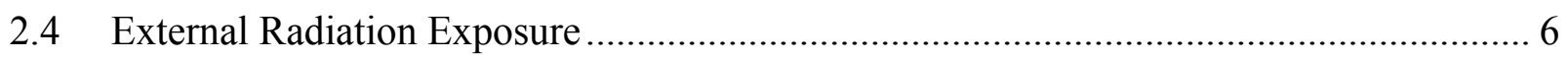

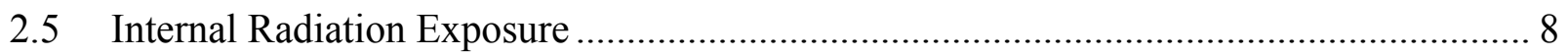

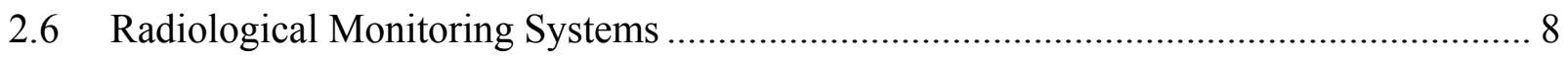

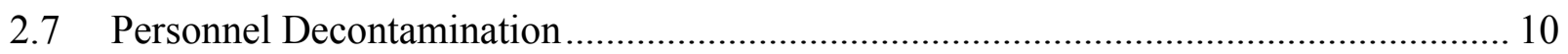

2.8 Facility Operations, Maintenance, Decontamination, and Decommissioning ................ 10

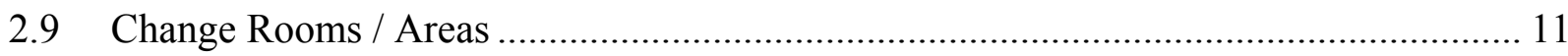

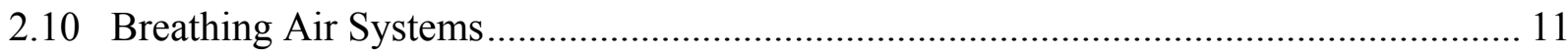

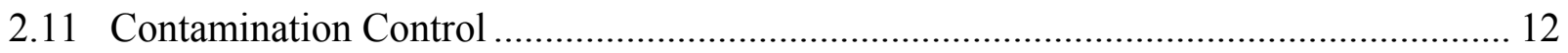

2.12 Material Radiation Tolerance and Compatibility ....................................................... 14

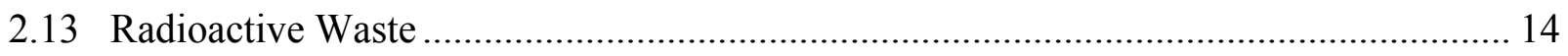

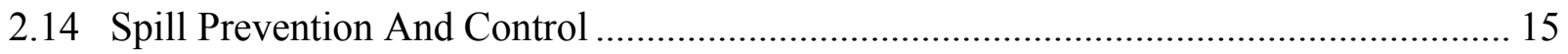

2.15 Radiological Control Space Requirements............................................................. 15

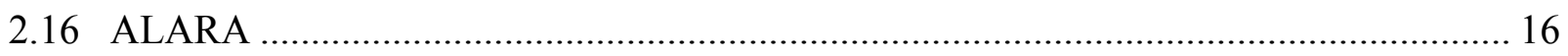

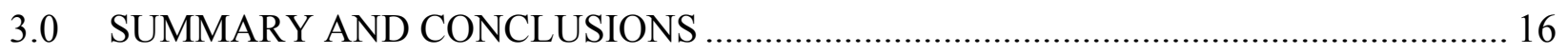

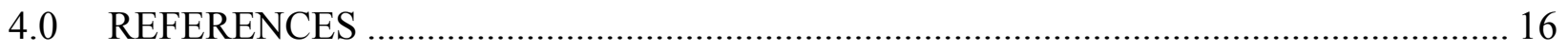

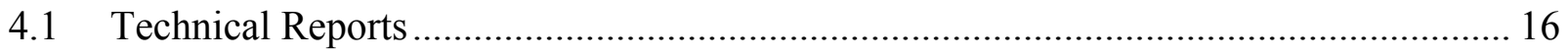

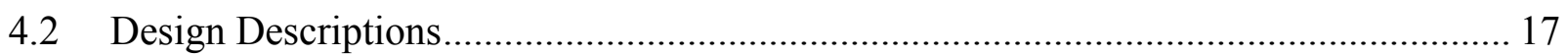

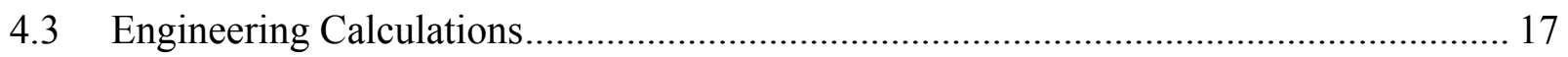

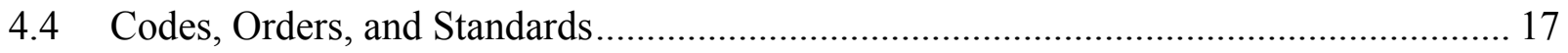

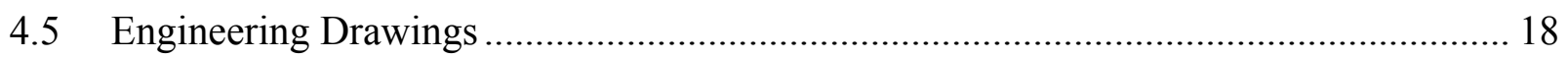

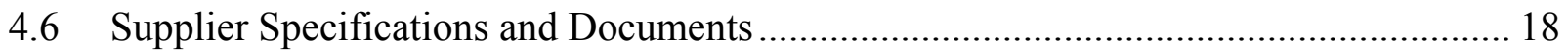

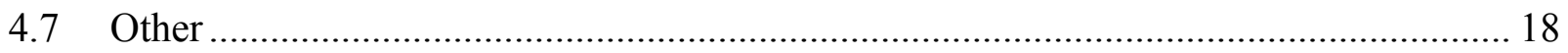

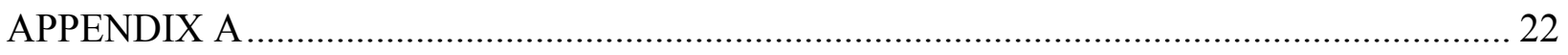




\section{LIST OF TABLES}

Table 2-1 Design Basis Annual Occupational Radiation Exposure Limits .................................... 5

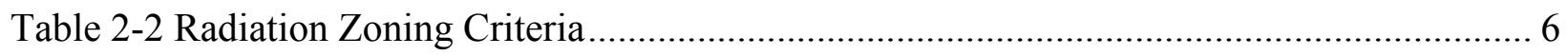

Table 2-3 Retrospective Air Sampler Locations...................................................................... 9

\section{LIST OF FIGURES}

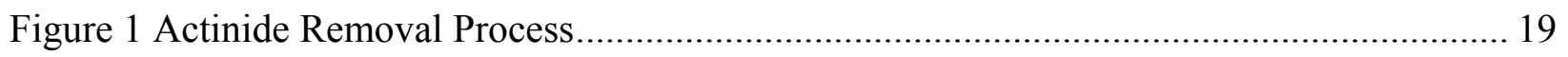

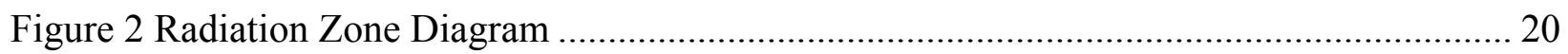

Figure 3 ARP Process Vessel Ventilation System................................................................. 21 
WSRC-TR-2003-00167

REVISION 0

\section{LIST OF ACRONYMS}

\section{Acronym /}

$\begin{array}{ll}\text { ALARA } & \text { As Low As Reasonably Achievable } \\ \text { APP } & \text { Auxiliary Pump Pit } \\ \text { ARP } & \text { Actinide Removal Process } \\ \text { CCTV } & \begin{array}{l}\text { Closed Circuit Television } \\ \text { Committed Effective Dose Equivalent } \\ \text { CEDE }\end{array} \\ \text { Code of Federal Regulations } \\ \text { DAC } & \text { Derived Air Concentration } \\ \text { DCS } & \text { Distributed Control System } \\ \text { DOE } & \text { Department of Energy } \\ \text { DWPF } & \text { Defense Waste Processing Facility } \\ \text { HDBK } & \text { Handbook } \\ \text { HEPA } & \text { High-Efficiency Particulate Air } \\ \text { HLW } & \text { High Level Waste } \\ \text { HPT } & \text { Health Physics Technology } \\ \text { HVAC } & \text { Heating, Ventilation, and Air Conditioning } \\ \text { ITP } & \text { In-Tank Precipitation } \\ \text { LCS } & \text { Local Control Station } \\ \text { LWF } & \text { Late Wash Facility } \\ \text { LWHT } & \text { Late Wash Hold Tank } \\ \text { LWPT } & \text { Late Wash Precipitate Tank } \\ \text { PVV } & \text { Process Vessel Ventilation } \\ & \text { Radiation Area } \\ \text { RA } & \text { Radiological Control } \\ \text { RadCon } & \text { Radiological Buffer Area } \\ \text { RBA } & \text { Savannah River Site } \\ \text { SRS } & \text { Total Effective Dose Equivalent } \\ \text { TEDE } & \text { Uninterruptible Power Supply } \\ \text { UPS } & \text { Westinghouse Savannah River Company } \\ \text { WSRC } & \end{array}$


WSRC-TR-2003-00167

REVISION 0

This page intentionally left blank. 
WSRC-TR-2003-00167

REVISION 0

\section{$1.0 \quad$ INTRODUCTION}

Manual WSRC-TM-95-1, Engineering Standard Number 01064 [4.4.3a], presents the radiological design criteria and requirements, which must be satisfied for all SRS facility designs. The radiological design criteria and requirements specified in the standard are based on 10CFR835 [4.4.1a], DOE Order 420.1A [4.4.2a], the WSRC Manual 5Q [4.4.3.b], other applicable standards, and various DOE guides and handbooks.

This report contains top-level requirements for the various areas of radiological protection for workers. Detailed quotations of the requirements for applicable regulatory documents can be found in the Radiological Design Summary Report Implementation Guide [4.1.a]. For the purposes of demonstrating compliance with these requirements, per Engineering Standard 01064, shall consider / shall evaluate indicates that the designer must examine the requirement for the design and either incorporate or provide a technical justification as to why the requirement is not incorporated.

This report describes how the Building 512-S, Actinide Removal Process meets the required radiological design criteria and requirements based on 10CFR835, DOE Order 420.1A, WSRC Manual 5Q and various other DOE guides and handbooks. The analyses supporting this Radiological Design Summary Report initially used a source term of $10.6 \mathrm{Ci} /$ gallon of Cs-137 as the basis for bulk shielding calculations [4.3.h]. As the project evolved, the source term was reduced to $1.1 \mathrm{Ci} /$ gallon of Cs-137 [4.2.1.a]. This latter source term forms the basis for later dose rate evaluations.

\subsection{Project Description}

In 2002, the High Level Waste (HLW) Salt Disposition Team was tasked with pursuing the implementation of an Actinide Removal Process (ARP), which maximizes the use of existing infrastructure. After an investigation identified several options, a study was performed to select an option for implementation. This study was concluded with a proposal to use the 512-S Facility, its filtration equipment, and tankage as part of the approach to implementing the ARP for the HLW System. This approach consists of:

- Restoration - - Modification of the 512-S Facility to resolve outstanding legacy issues and perform identical, like for like and alternate replacement of unserviceable or obsolete equipment, sufficient to provide a generic waste treatment facility.

- ARP Hot Operations - Modifying the 512-S Facility to perform actinide removal.

- ARP Enhanced Capacity - Expanding the processing capacity of the 512-S Facility, using Building 241-96H.

This report deals with the second of these steps, ARP Hot Operations.

The 512-S Facility is currently a DOE Non-Reactor Nuclear Facility. The 512-S Facility comprises of the following buildings and support structures [4.2.1.a]:

- 512-S, Process Building

- 512-1S, HEPA Filter Building

- 512-2S, Instrument Shelter Room

- 512-4S, Primary Nitrogen Storage Pad 
- 512-5S, Backup Nitrogen Storage Pad

- 512-6S, Laboratory

- 512-7S, Cold Chemical Storage Area

Figure 1 depicts the ARP.

\subsection{Facility Description}

The 512-S Facility was originally designed as the Auxiliary Pump Pit (APP) as part of the Defense Waste Processing Facility (DWPF) and later modified and commissioned as the Late Wash Facility (LWF). The Process Building (512-S) is the main building for the ARP. It is one story, divided into a High Bay (Process Area) and a Low Bay (Service Area). The Process Area consists of a below grade structural concrete pit internally divided into three deep stainless steel lined cells, capped with remotely removable reinforced segmented concrete cell covers. The individual cells house equipment necessary for the chemical and filtration processes. Each of the three cells is equipped with a sump to collect leakage and spillage. A Backpulse Tank Vault is located at grade and an overhead crane is provided for servicing the Process Area. The Service Area contains the Electrical Rooms, a Battery Room, Change Rooms, Offices, the Crane Control Room, a Vacuum Blower Room, the Instrument Control Valve Gallery, and the Control Room.

Attached to the south end of Building 512-S is the Instrument Shelter (512-2S) and adjacent to this is the HEPA Filter Building (512-1S) which houses the Process Vessel Vent and Process Ventilation HEPA filter banks. A small laboratory (512-6S) is located to the East of the Process Building. A laboratory sampling system is provided. Located to the North of the Process building are the Primary and Backup Nitrogen Storage Pads (512-4S and 512-5S respectively) and a Cold Chemical Storage Area (512-7S) that provides a centralized location for the delivery, storage, and supply of cold feed chemicals to Building 512-S.

To support the process, the Chemical Cleaning System provides for transfer of filter cleaning fluids in the amounts required for filter wet lay-up or chemical filter cleaning operations. The Process Vessel Vent System supplies fresh filtered air to the cells. There are two air intake HEPA filters, one in service and the other in standby, which mitigate the potential release of radioactive particulates in the event of a flow reversal from the cells to the environment.

The Heating, Ventilating and Air Conditioning (HVAC) System provides and maintains environmental climate control, for the purposes of personnel comfort and equipment operational stability and longevity, in the laboratory and the rooms of Building 512-S, including offices.

The Domestic Water System supplies water to a process water system. The water systems that contain above ground piping are provided with freeze protection via heat tracing and insulation.

Primary and backup nitrogen systems are also provided. The major uses of the Nitrogen System are flammability control, sparging (not used in actinide removal process), backpulsing, instrumentation/level, and valve operator motive force.

The Electrical Distribution and Load Center receives electrical power from the H-Area $13.8 \mathrm{kV}$ system. The $13.8 \mathrm{kV}$ power is stepped down, distributed through a $1000 \mathrm{KVA}$ transformer to $480 \mathrm{VAC}$ power, routed to the motor control center (MCC) cabinets in the electrical control and equipment rooms, and then distributed to the 512-S Facility. 
An Uninterruptible Power Supply (UPS) supplies power to critical Distributed Control System (DCS) loads, which ensures continued operation of the DCS equipment during all phases of operation.

Other support services and the balance of plant processes, including utilities, process support, structural systems, and infrastructure/habitability services are provided to support the operation of 512-S Facility systems and operating/maintenance personnel, to ensure safety while operating.

A Fire Detection and Alarm System is provided, which consists of a detection and alarm function provided by the sensed changes in the sprinkler system operation. A dry pipe sprinkler subsystem is provided for the Process Building and a wet pipe sprinkler subsystem serves the Laboratory Building. Fire water is supplied from the H-Area firewater distribution loop to each sprinkler system.

\subsection{Facility Conditions}

\subsubsection{Normal Operations}

During radioactive operations, the 512-S Facility may be operated 24 hours/day, 7 days/week. Operation of this facility will be accomplished using a complement of existing Operators and Supervisors at the DWPF. A standard 12-hour shift rotation will be worked. An adequate staffing of support personnel, including Maintenance, Engineering and Radiological Control, provide coverage at the 512-S Facility and the other facilities at the DWPF.

Operations activities are performed using approved procedures in accordance with Site approved Manuals and Procedures. As necessary, these procedures incorporate precautions, warnings, and lessons learned.

Day to day operations are accomplished using a Distributed Control System (DCS) from the 210-S Control Room. System operating parameters and alignments can be controlled and monitored remotely using the DCS. Local Control Stations (LCS) are also available to locally control and monitor system operating parameters and alignments.

\subsubsection{Shutdown Operations}

During shutdown mode the equipment within the process cells may be surface decontaminated using the in-cell spray headers. Internal flushing of the system and wet/dry lay-up of the Cross-Flow Filter will be performed. Maintenance may be performed remotely using the overhead crane in conjunction with the giraffe and crane mounted CCTV. Temporary facilities may be erected to allow further decontamination of removed equipment prior to maintenance or removal.

\subsubsection{Maintenance Operations}

Maintenance activities will be performed using approved procedures/work packages in accordance with WSRC Manual 1Y, "Conduct of Maintenance." As necessary these procedures/work packages will identify associated precautions and applicable maintenance history information.

Due to the high radiation levels during operations mode, no maintenance will be performed inside the process cells and in the Backpulse Tank Vault due to the potential for personnel exposure. Hands on maintenance will be performed as required in all other areas of the facility. 
WSRC-TR-2003-00167

REVISION 0

If cell covers are removed, maintenance may be performed remotely using the overhead crane in conjunction with the giraffe and crane mounted CCTV. Temporary facilities may be erected to allow decontamination of removed equipment prior to maintenance or removal.

\subsubsection{Transient Operations}

There are no transient operations associated with the Actinide Removal Process.

\subsubsection{Postulated Events and Accident Conditions}

The accident conditions that impact radiological design include [4.1.b]:

- Damage to the cell covers which could cause exposure of operating personnel to high radiation fields due to direct radiation from the tanks or the Cross-Flow Filter.

- Back flow of filtrate through the Backpulse Tank to the cold chemical supply area or the nitrogen supply area. This accident could cause personnel who are not radiological workers to be exposed to high radiation fields.

- Operator enters Backpulse Tank Vault during operations. The Consolidated Hazards Analysis Process determined that this was an anticipated event with high consequences to the facility worker due to direct radiation coming from the material in the process piping contained in the cell. The Backpulse Tank Vault is the only cell in the 512-S Facility that is accessible to facility workers during normal operations. Entry could be gained to the cell through the access door of the cell.

\subsection{DESIGN REQUIREMENTS}

This section presents the technical basis for how the design ensures compliance with applicable requirements for each facility condition, including normal, shutdown, maintenance, transient, and postulated events and accidents.

\subsection{Radiation Exposure Limits}

\section{Per SRS Engineering Standard 01064:}

Design features shall ensure that the radiation exposure design limits are ALARA and shall not exceed $20 \%$ of the regulatory limits in 10CFR835. The internal CEDE design limit is per [Westinghouse Savannah River Company 2001 ALARA Goals]. A total of 2000 hours shall be used as worker stay times for areas of continuous occupancy. Table 2-1 summarizes the design basis radiation exposure limits. 
WSRC-TR-2003-00167

REVISION 0

Table 2-1 Design Basis Annual Occupational Radiation Exposure Limits

\begin{tabular}{|l|c|}
\hline Type of Exposure & Limit (rem) \\
\hline Whole Body TEDE (internal + external) & 1.0 \\
\hline Internal CEDE & 0.1 \\
\hline Lens of Eye & 3 \\
\hline Extremity & 10 \\
\hline Any Organ (other than eye) or Tissue & 10 \\
\hline
\end{tabular}

The dose to any member of the public or a minor exposed to radiation at a DOE facility shall not exceed 0.1 rem Total Effective Dose Equivalent in a year.

The 512-S Facility is an existing structure that is being modified for a different use. The shielding analyses performed [4.3.a through 4.3.d] showed that the existing shield structures provide adequate attenuation for the radiation emitted by the sources associated with the ARP and that the limits in Table 2-1 are not exceeded.

\subsection{Facility and Equipment Layout}

\section{Per SRS Engineering Standard 01064:}

Facility layout shall be based on segregation of facility functional areas.

There are no lunchrooms located in the 512-S Facility. Restrooms, showers, and office spaces are located in Continuous Occupancy (Zone V) areas separated from the Process Area [4.5.a].

\subsection{Access Control}

\section{Per SRS Engineering Standard 01064:}

Minimizing the number of entry points into a Radiological Buffer Area (RBA) shall be considered such that appropriate qualifications can be checked and access controlled. Within the RBA, appropriate entry control features shall be established for each radiological area per [10CFR835]. The degree of control shall be commensurate with existing and potential radiological hazards within the area. No control(s) shall be established in a high or very high radiation area that would prevent rapid evacuation of personnel. All radiological access control features shall be consistent with the site radiological access control program.

Access to the Operating Area is through Radiological Corridor (room 118) [4.5.a]. The Filter Cell, Filtrate Cell, and Precipitate Cell are inaccessible during normal operations since they are below grade with cell covers in place. The Backpulse Tank Vault has a locked door to prevent access during operation [4.7.a]. 


\subsection{External Radiation Exposure}

This section deals with external radiation exposures and addresses whether engineered design features are required to limit worker exposures to ALARA below the Table 2-1 external exposure limits.

\subsubsection{Area Radiation Levels}

\section{Per SRS Engineering Standard 01064:}

Compliance with the ALARA process and the regulatory dose limits is accomplished in part by designing radiological portions of the facility to meet predetermined maximum area radiation dose rate levels. The radiation zoning criteria for the facility is given in Table 2-2.

Table 2-2 Radiation Zoning Criteria

\begin{tabular}{|c|c|l|}
\hline Zone Definition & $\begin{array}{l}\text { Maximum Design } \\
\text { Dose Rate (mrem/hr) }\end{array}$ & Description \\
\hline I & $>100$ & $\begin{array}{l}\text { High Radiation Area } \\
\text { Positive Control Required }\end{array}$ \\
\hline II & $\square 100$ & $\begin{array}{l}\text { Radiation Area (RA) } \\
\text { Controlled Area }\end{array}$ \\
\hline III & $\square 5$ & $\begin{array}{l}\text { Limited Occupancy } \\
\text { Controlled Area }\end{array}$ \\
\hline IV & $\square 0.5$ & $\begin{array}{l}\text { Continuous Occupancy } \\
\text { Radiological Controls (RBA) }\end{array}$ \\
\hline $\mathrm{V}$ & $\square 0.05$ & $\begin{array}{l}\text { Unlimited Occupancy } \\
\text { No Radiological Controls }\end{array}$ \\
\hline
\end{tabular}

Radiation zones are defined based on expected occupancy and mode of operation; these are shown on Figure 2 [4.5.a].

\subsubsection{Radiation Shielding}

\section{Per SRS Engineering Standard 01064:}

Radiation shielding may be designed using any applicable method... Selection of shield materials shall also consider minimization of hazardous materials (e.g., lead) and/or the encasing of such materials to preclude the generation of a mixed waste.

For glovebox designs, shielding for radiation sources inside the glovebox shall be considered in addition to glovebox structural shielding. In addition, shield covers or plugs shall be supplied for each gloveport with shielding equivalent to the glovebox if the potential exists that material in the glovebox will cause dose to personnel other than those directly handling the sources during processing operations.

The 512-S Facility is an existing structure that is being modified for a different use. The shielding analyses performed [4.3.a through 4.3.d] evaluated the effect of changes in sources on the existing shield walls. These analyses showed that with the cell covers in place, the existing shield structures provide adequate attenuation for the radiation emitted by the sources associated 
with the ARP during normal operations. For the Backpulse Tank Vault, this conclusion is based on limiting the source in the Backpulse Tank to less than $1.1 \mathrm{Ci} /$ gallon of Cs-137.

Shutdown and maintenance operations may require remote handling of components with a cell cover removed. One such operation would be the replacement of a Cross-Flow Filter, which could still contain residual radioactive material in its pores. If it is necessary to replace the Cross-Flow Filter, a specially designed shielded container will be used to reduce dose rates that might be observed outside the 512-S Facility. The dose rates outside the facility during removal of the Cross-Flow Filter (based on 1.1 Ci/gallon Cs-137 in the Filtrate) will be within acceptable levels [4.3.e]. This analysis, which was based on scaling dose rates calculated for ITP, is conservative for this project since the ITP plugging mechanisms are conservative for ARP (see Appendix A).

\subsubsection{Penetrations}

\section{Per SRS Engineering Standard 01064:}

Straight-line penetrations of shield walls shall be avoided to the extent necessary to prevent radiation streaming. All penetration configurations in radiation shield walls shall be evaluated to ensure compliance with the radiation zone criteria. Higher, localized dose rates will require a case-by-case approval by the Radiological Technology Group of HPT.

The design shall consider guidance from [HDBK-1132-99] Part II Section 1.4.3 [4.4.2.b] on radiation shielding penetration seals and shall incorporate requirements from [Engineering Standard 07270, Installation and Inspection of Penetration Seals].

The only straight-line penetrations in the operating areas are the ventilation duct for the Backpulse Tank Vault (an eight inch pipe) which is located in the southeast corner of the vault over eight feet above the operating floor and a valve reach rod penetration in the sampler line shielding. The penetration for the ventilation duct has no direct line of sight to the piping that carries the Filtrate through the Backpulse Tank Vault. The attenuation of the penetration and air scattering from the exit to personnel locations provides sufficient reduction in the dose rate ${ }^{1}$. The valve reach rod penetration is backfilled with lead wool to prevent streaming.

\subsubsection{Extremity And Eye Protection}

\section{Per SRS Engineering Standard 01064:}

Specialized tools and remote handling equipment, such as remote manipulators, shall be considered where it is anticipated that exposures to extremities and eyes would otherwise approach the dose limits in Table 2-1 or where contaminated puncture wounds could occur.

1 The attenuation of an eight inch cylindrical duct in a two foot thick wall is estimated as: $\mathrm{D} / \mathrm{D}_{0}=0.125(\mathrm{~d} / \mathrm{L})^{2}=0.125(8 / 24)^{2}=0.014$. The attenuation due to air-scatter down to a receptor one foot from the exit and two feet down is estimated as less than 0.1 giving a total attenuation of 0.001 . This is less that the attenuation factor for two feet of concrete $(0.01$ for fission product gamma rays). 
WSRC-TR-2003-00167

REVISION 0

The ARP does not involve hands-on operations. All maintenance on radioactive components will be performed remotely. Thus, there are no situations that would involve exposure to the extremities that are different from whole body exposure.

\subsection{Internal Radiation Exposure}

\section{Per SRS Engineering Standard 01064:}

The design shall ensure that respiratory personnel protective equipment is not required to meet the dose limits for operations including normal, shutdown, maintenance, transient, and postulated events and accidents. Engineered controls and features shall be provided to minimize potential inhalation of radioactive and other hazardous material under all operating conditions.

The design of the 512-S Facility (processing in separate cells with air flow to prevent the spread of contamination) makes it unlikely that exposure of personnel will exceed the regulatory limits. Calculations of the buildup of airborne activity [4.3.f] demonstrate that in the unlikely event of a spill in one of the process cells, the operators would have more than fourteen minutes to evacuate prior to reaching the administrative limit of 40 DAC-hours.

\subsection{Radiological Monitoring Systems}

\section{Per SRS Engineering Standard 01064:}

Radiological warning and alarm systems shall be designed, installed, and tested to ensure that they can be heard in the ambient condition of the area they are intended to cover. All radiological alarm systems required for personnel protection shall annunciate inside and outside the affected area to identify hazardous condition to anyone inside or outside in the vicinity of the affected area. All radiological alarms shall be provided with both audible and visual signaling systems. The audible alarm shall have the capability to be acknowledged while the visual alarm remains. Alarm noise level guidance is contained in [Engineering Guide 01061-G].

In addition to a local station alarm, radiation monitoring system signals in new facilities shall have central (e.g., control room or radiation monitoring office) read-out and alarm panels that are accessible after anticipated events to evaluate internal conditions. For modified facilities, the use of central read-out and alarm panels shall be considered.

For glovebox design, the use of an audible and visual alarm that can be manually activated (e.g., foot pedal, within glovebox trouble button, etc.) to signal radiological problems without removing one's arms from the glovebox shall be evaluated. The alarm shall occur in continuously occupied areas, identify the room of concern, and be uniquely identifiable versus other alarm signals.

The two area radiation monitors near the HEPA Filters will have local alarms and will alarm in the 210-S Control Room. The area radiation monitors near the piping outside Building 512-S will have local alarms and alarms in the 512-S High Bay as well as in the 210-S Control Room. 


\subsubsection{Airborne Sampling and Monitoring}

\section{Per SRS Engineering Standard 01064:}

Air sampling shall be performed in occupied areas where an individual is likely to be exposed to 40 DAC-hrs over a one year period of airborne radioactive material.

Guidance on placement of samplers, in order to comply with the SRS program, is given in [The Savannah River Site Workplace Air Monitoring Technical Basis Manual]. The design shall also evaluate particulate line loss as necessary between the sampling location and sample collection media.

Continuous air monitoring equipment shall be installed in occupied areas as necessary to detect and warn personnel of airborne radioactive material concentrations which could result in exceeding Section 2.1 dose limits prior to detection by sampling. Guidance on placement of monitors, in order to comply with the SRS program, is given in [The Savannah River Site Workplace Air Monitoring Technical Basis Manual]. The design shall also evaluate particulate line loss as necessary between the monitoring location and sample collection media.

\section{Per 10CFR835.403(b):}

Real-time air monitoring shall be performed as necessary to detect and provide warning of airborne radioactivity concentrations that warrant immediate action to terminate inhalation of airborne radioactive material.

The design of the 512-S Facility (processing in separate cells with air flow to prevent the spread of contamination) makes it unlikely that an exposure of 40 DAC-hours in a week will be exceeded. It is also unlikely that airborne radioactivity will unexpectedly increase (spills would be into the cells and then would have to diffuse through the covers into the high bay despite the normal ventilation flow pattern that draws air into the cells). Calculations of the buildup of airborne activity [4.3.f] demonstrate that in the unlikely event of a spill in one of the process cells, the operators would have more than fourteen minutes to evacuate prior to reaching the administrative limit of 40 DAC-hours. Thus, only retrospective air samplers are provided at the following locations:

Table 2-3 Retrospective Air Sampler Locations

\begin{tabular}{|l|l|l|l|}
\hline Designation & Location & Designation & Location \\
\hline RE-0935 & High Bay East Wall North & Portable & Valve Gallery \\
\hline RE-0936 & High Bay East Wall South & Portable & HEPA Filter Room \\
\hline RE-0937 & High Bay West Wall North & Portable & Sample Room in 512-6S \\
\hline RE-0938 & High Bay West Wall South & Portable & PVV Room \\
\hline RE-0939 & Process Area West Wall & & \\
\hline
\end{tabular}

\subsubsection{Personnel Contamination Monitoring}

\section{Per SRS Engineering Standard 01064:}

The design shall provide for the monitoring of occupational workers in work areas where radioactive materials (other than tritium only) are stored and handled. Appropriate whole body personnel contamination monitoring equipment shall be provided at the exit from all Contamination and Radiological Buffer Areas where potential for contamination 
WSRC-TR-2003-00167

REVISION 0

(other than tritium only) exists, to prevent the spread of contamination. The background radiation dose rate for personnel contamination monitors must be designed to meet the specifications of the unit (typically $<0.02 \mathrm{mrem} / \mathrm{hr}$ for automated systems).

Personnel contamination monitors are located in the "Controlled Corridor" (Room 117) near the Clean Change Rooms [4.5.a].

\subsubsection{Area Radiation Monitoring Per SRS Engineering Standard 01064:}

Area radiation monitors shall be installed in occupied locations with the potential for an unexpected increase in dose rates and in locations where there is a need for local indication of dose rate prior to personnel entering remote locations.

There are no areas in the 512-S High Bay with a potential for an unexpected increase in dose rates. The cell cover design precludes the possibility of incorrectly installing the covers. The Backpulse Tank Vault access door is locked and may not be opened during operations involving radioactive material in the vault [4.7.a].

The HEPA Filter Room and PVV Room have the potential for unexpected increase in dose rate if high activity material should become trapped on the HEPA filters. Existing area radiation monitors (RE-0944 and RE-0945) in these locations will remain in service during ARP Hot Operations.

The area between Building 512-S and Building 512-6S contains piping for the Nitrogen Supply System and the Chemical Distribution System. A postulated design basis accident involves back flow of Filtrate through the Backpulse Tank to these systems. This accident could cause personnel who are not radiological workers to be exposed to high radiation fields. Area radiation monitors are included in this area to alert personnel to evacuate the area [4.7.c].

\subsection{Personnel Decontamination}

\section{Per SRS Engineering Standard 01064:}

The facility shall provide for a personnel decontamination facility close to the area that represents the source of potential contamination. The use of nearby, existing decontamination resources shall be considered.

In the unlikely event that personnel require decontamination, the facilities located in $210-\mathrm{S}$ will be used.

\subsection{Facility Operations, Maintenance, Decontamination, and Decommissioning Per SRS Engineering Standard 01064:}

The design or modification of a facility and the selection of materials shall include features that facilitate operations, maintenance, decontamination, and decommissioning.

The facility design shall incorporate measures to simplify decontamination of areas that may become contaminated with radioactive or hazardous materials.

The 512-S Facility is an existing structure that is being modified for a different use. The cells in 512-S are steel lined which will facilitate decontamination and decommissioning. 
The 512-S Facility does not have facilities for remote maintenance of contaminated equipment. Remote decontamination and maintenance of equipment are performed at the DWPF

Vitrification Building maintenance facilities. Contaminated equipment requiring maintenance is transported between the 512-S Facility and the Vitrification Building in sealed, shielded transport boxes, as necessary. Temporary facilities may be erected to allow further decontamination of removed equipment prior to maintenance or removal. Dose rates associated with removal of the cell covers due to the residual heel (191 gallons [4.3.h]) in the equipment are expected to be less than $5 \mathrm{mrem} / \mathrm{hr}[4.3 . \mathrm{g}]$.

\subsection{Change Rooms / Areas}

\section{Per SRS Engineering Standard 01064:}

Men's and women's change rooms shall be provided for changing into and out of modesty clothing if areas within the facility will require work in protective clothing on a routine basis. The use of nearby, existing change rooms shall be considered. Change areas for the removal of protective clothing shall be provided at the exit of areas that have the potential to become contaminated. These areas shall provide space for protective clothing removal and personnel monitoring. These areas shall ensure that storage of contaminated clothing will control contamination so that it does not spread beyond the storage container.

\section{Per SRS Engineering Standard 15889:}

Where analysis determines that HEPA filtration is required to prevent radiation exposure or fissile material buildup in the exhaust ductwork, then the exhaust ductwork system shall consist of a testable bag-in bag-out HEPA filter, as close to the source as possible. A manual or automatic balancing device is also required to adjust airflow as the HEPA filter becomes loaded [Section 5.7.1.3].

HEPA filters are required in exhaust systems where the airborne radiological concentration can potentially reach 1 DAC or greater at the point of discharge of the facility (i.e., stack or equivalent discharge point for subordinate facilities) [Section 5.7.1.6].

Change rooms (Rooms 119 and 120) are located in the northwest area of Building 512-S. This is a Continuous Occupancy (Zone V) area separated from the Process Area [4.5.a]. Only liquid waste is processed in ARP so there are no dispersible radionuclides handled.

\subsection{Breathing Air Systems}

\section{Per SRS Engineering Standard 01064:}

Operations and maintenance of special facilities may lead to situations (e.g., accidents, special maintenance, spill recovery) where air-supplied respiratory protection is required. For modifications, the use of existing breathing air manifolds shall be considered.

It is not anticipated that breathing air will be needed during Actinide Removal Process operations because the sources are all contained. If needed, breathing air for the 512-S Facility is provided by portable cylinders or a portable breathing air compressor. 
WSRC-TR-2003-00167

REVISION 0

\subsection{Contamination Control}

This section addresses whether engineered design features are required for contamination control in order to limit worker exposures to ALARA below the Table 2-1 exposure limits.

\subsubsection{Confinement}

\section{Per SRS Engineering Standard 01064:}

The facility shall be provided with a confinement system to prevent the migration of radioactive materials from confinement enclosures, containment vessels, process equipment and their associated ventilation systems to occupied and unoccupied work areas. Design of confinement systems shall ensure compliance with both the internal and external radiation exposure limits contained in Section 2.1.

\section{Per 10CFR835.1002(c):}

Regarding the control of airborne radioactive material, the design objective shall be under normal conditions, to avoid releases to the workplace atmosphere and in any situation, to control the inhalation of such material by workers to levels that are ALARA; confinement and ventilation shall normally be used.

\section{Per HDBK-1132-99, Part I, Section 1.1.2:}

Confinement system features, including confinement barriers and associated ventilation systems, are used to maintain controlled, continuous airflow from the environment into the confinement building, and then from uncontaminated areas of the building to potentially contaminated areas, and then to normally contaminated areas.

The 512-S Facility design includes processing in separate cells with airflow from areas of low contamination potential through areas with higher contamination potential and eventual HEPA filtration prior to discharge to the atmosphere.

\subsubsection{Ventilation}

\section{Per SRS Engineering Standard 01064:}

Confinement ventilation design requirements are located in SRS Engineering Standard 15889 [4.4.3.d].

The 512-S Facility design includes processing in separate cells with airflow from areas of low contamination potential through areas with higher contamination potential and eventual HEPA filtration prior to discharge to the atmosphere.

The PVV System collects vented gases from the Late Wash Hold Tank (LWHT), Late Wash Precipitate Tank (LWPT), and the Surge Tank and dilution air from the Precipitate, Filter and Filtrate Cells. This combined vent stream passes through a heater and a series of HighEfficiency Particulate Air (HEPA) filters before passing through an exhaust blower and out to the exhaust stack. There are two exhaust blowers, each with a pneumatically operated inlet damper and a manually operated outlet damper. Each blower is rated for $100 \%$ of system capacity. Normally, one exhaust blower is in operation and the other is in standby. There are four exhaust air HEPA filters arranged in parallel to remove radioactive particulates from the exhaust stream. Each exhaust HEPA filter has its own inlet and outlet isolation valve. Normally, three exhaust HEPA filters are in service and one is in standby. Prior to entering the 
HEPA filters, the temperature of the vent stream is increased above the dew point temperature by a heater to prevent moisture from condensing on the HEPA filters.

The PVV System also supplies fresh, filtered air to the Precipitate, Filter, and Filtrate Cells. An air intake heater heats incoming air as required to prevent the cell temperatures from dropping below $15^{\circ} \mathrm{C}$. There are two air intake HEPA filters, one in service and the other in standby. The HEPA filters prevent the potential release of radioactive particulates in the event of a flow reversal from the cells to the environment. A simplified P\&ID for the PVV System is shown in Figure 3.

\subsubsection{Access Ways}

\section{Per SRS Engineering Standard 01064:}

Special features (e.g., air locks, enclosed vestibules) shall be provided for access through confinement barriers to minimize the impact of facility access requirements on the ventilation system and to prevent the release of radioactive airborne materials.

There are air locks or enclosed vestibules in the 512-S Facility. Access to the process cells is controlled administratively by requiring that the cell covers be in place during processing operations. Likewise, access to the Backpulse Tank Vault is controlled by use of a locked door to prevent personnel access during operation.

\subsubsection{Transfer Pipes And Encasements}

\section{Per SRS Engineering Standard 01064:}

When a pipe is used as the primary confinement barrier for materials (excluding ventilation systems), and the pipe exits the facility, a secondary confinement shall be provided by a double-walled pipe or other encasement/spill control. In areas within the facility, the use of double-walled pipe shall be considered.

Where double-walled piping or encasements are employed, leak detection shall be provided for the primary pipe, which may include liquid detection, airborne contamination monitoring, or other means, in areas affecting personnel protection or the environment.

There shall be no interconnection among storm water systems, the sanitary waste systems, and the radioactive or other hazardous material handling systems or areas.

Chilled water systems shall be designed to minimize the volume of water that can be contaminated.

\section{Per HDBK-1132-99, Part II, Section 1.3.8:}

The routing of piping containing radioactive materials should consider the reduction of exposure levels to ALARA.

Piping that exits the process cells is core pipe inside a larger jacket. Piping is routed underground and beneath the concrete operating floor to provide adequate radiation protection for operating personnel [4.3.c]. 
WSRC-TR-2003-00167

REVISION 0

\subsection{Material Radiation Tolerance and Compatibility Per SRS Engineering Standard 01064:}

Materials inside radiation areas shall be capable of withstanding the total absorbed dose over the lifetime of the system, structure, or component. The use of Teflon or organic materials in radiological areas should be avoided.

No materials in the 512-S Facility have radiation tolerance concerns.

\subsection{Radioactive Waste}

\section{Per SRS Engineering Standard 01064:}

The facility design shall meet the general and facility specific waste requirements of DOE Order 420.1A Section 4.1.1.2.

\section{Per Manual 5Q, Article 441:}

Radiological operations generating radioactive waste shall be designed and developed to promote minimization and permit segregation, monitoring, treatment, storage, and disposal.

\subsubsection{Waste Management}

\section{Per SRS Engineering Standard 01064:}

The design requirements for storage, transfer, monitoring, surveillance, and leak detection of high-level and low-level radioactive wastes are stated in DOE Order 435.1 [4.4.2.c].

The design shall provide for decontamination and decommissioning, and waste disposal of radioactive material. The design shall limit dispersion of radioactive materials and simplify decontamination and decommissioning.

The 512-S Facility is an existing facility. During the Actinide Removal Process, operations in 512-S will be governed by the DWPF Waste Management Plan [4.7.b].

\subsubsection{Mixed Waste Requirements}

\section{Per SRS Engineering Standard 01064:}

Radioactive mixed wastes shall be avoided where practicable. Mixed waste that cannot be avoided shall be identified and considered in the design at the earliest possible time. Mixed waste shall be segregated and handled separately from the other types of wastes.

The 512-S Facility is an existing facility. During the Actinide Removal Process, operations in 512-S will be governed by the DWPF Waste Management Plan [4.7.b].

\subsubsection{Waste Segregation}

\section{Per SRS Engineering Standard 01064:}

The facility design shall provide for the segregation of waste into compatible groups for storage and disposal. 
WSRC-TR-2003-00167

REVISION 0

The 512-S Facility is an existing facility. During the Actinide Removal Process, operations in 512-S will be governed by the DWPF Waste Management Plan [4.7.b].

\subsection{Spill Prevention And Control}

\section{Per SRS Engineering Standard 01064:}

Spill prevention and control shall be considered in the design stage of the facility to minimize the possibility of accidentally releasing radioactive material to the environment.

\section{Per DOE-HDBK-1132-99, Part I, Section 2.1.2:}

The piping system that collects contaminated liquids should be designed so that effluents from leaks in the system can be collected without releasing the liquids into the personnel access areas or to the environment.

\section{Per DOE-HDBK-1132-99, Part I, Section 2.8.2:}

The use of multiple barriers should be emphasized when necessary to restrict the movement of radioactive liquid waste that has the potential for human contact or for reducing groundwater quality below requirements.

Spills, overflow, or leakage from storage vessels or other primary confinement structures should be collected and retained within a suitable secondary confinement structure (e.g., secondary vessel, dike or berm, elevated threshold within a storage or process building, etc.). The secondary confinement structure should be able to retain the maximum radioactive liquid waste inventory that may be released by a spill, overflow, or leak from the primary confinement structure.

All process cells are equipped with sumps to collect any leakage that may occur during process operations. Process lines that exit the cells are double encased pipes.

\subsection{Radiological Control Space Requirements}

\section{Per SRS Engineering Standard 01064:}

The facility shall contain designated areas for radiological support functions.

Specifically, space is required for a Radiological Control (RadCon) Office, instrument storage and decontamination areas, RadCon supervisors office, desk space for RadCon inspectors, counting equipment, and records storage. The design shall evaluate the power supply and environmental needs of the counting equipment required to operate during routine and non-routine conditions.

Space for radiation monitoring equipment shall be available in shipping and receiving areas for surveying the contamination level on the surface of shipping containers and other radioactive material received from or to be shipped off-site and on-site.

An "HP Area" and "Radiological Corridor" (Rooms 116 and 118) are located in the northwest area of Building 512-S. This is a Continuous Occupancy (Zone V) area separated from the Process Area [4.5.a]. 
WSRC-TR-2003-00167

REVISION 0

\subsection{ALARA}

\section{Per SRS Engineering Standard 01064:}

Radiation exposure of the work force and public shall be controlled such that radiation exposures are well below regulatory limits and that there are no radiation exposures without commensurate benefit.

Measures shall be taken to maintain radiation exposure ALARA through facility and equipment design and administrative control. The primary methods used shall be physical design features (e.g., confinement, ventilation, remote handling, and radiation shielding). Administrative control and procedural requirement shall be employed only as supplemental methods to control radiation exposure.

Optimization principles shall be utilized in developing and justifying facility shield design as early as possible in the design effort. A value of $\$ 6,600 /$ person-rem shall be used in the optimization analysis when the design limit TEDE of $1000 \mathrm{mrem}$ is used. If a TEDE limit less than that required in Section 2.1 is used, then the cost per person-rem can be taken from [S-CLC-G-00253]. The design objective for personnel exposure from all sources of radiation is to reduce doses to ALARA and below the Table 2-1 design basis dose limits.

The 512-S Facility is an existing structure that is being modified for a different use. The shielding analyses performed [4.3.a through 4.3.d] evaluated the effect of changes in sources on the existing shield walls and concluded that there was adequate attenuation for the radiation emitted by the sources associated with the ARP. At an average dose rate of approximately $0.25 \mathrm{mrem} / \mathrm{hr}$ on the operating floor, and continuous occupancy of 2000 hours per year, the personnel exposure would be 0.5 person-rem per year for each operator. Assuming four operators and ten years operation of ARP, the total exposure would be 20 person-rem. Using $\$ 6,600$ per person-rem avoided, the justifiable expenditure for eliminating all personnel exposure would be $\$ 132,000$. Since the dose is accumulated in small increments dispersed over many areas, the cost associated with the engineering, design and construction/purchase of physical safeguards to reduce a substantial portion of the dose would far exceed the dollar amount of dose savings. It has been shown that design basis dose rates will meet the radiation zone criteria shown in Figure 2, and the doses will be ALARA below the exposure limits shown in Table 2-1 for this existing facility.

\subsection{SUMMARY AND CONCLUSIONS}

The radiological design requirements specified in SRS Engineering Standard 01064, 10CFR835, DOE Order 420.1A, WSRC Manual 5Q, and other applicable documents, have been addressed. The above sections present the technical basis for the radiological design for 512-S Facility meeting these radiological design requirements.

\subsection{REFERENCES}

\subsection{Technical Reports}

a) T. L. White, Ed., Radiological Design Summary Report Implementation Guide, WSMS-CRT-02-0048, Rev 0, WSMS, July 2002. 
WSRC-TR-2003-00167

REVISION 0

b) E. Thomas, and T. G. Hayes, Actinide Removal Process (ARP) and DWPF Transfer Lines Consolidated Hazard Analysis (U), WSRC-TR-2002-00223, Revision 1, WSMS, July 2003.

\subsection{Design Descriptions}

\subsubsection{Facility Design Description}

a) Facility Design Description, Actinide Removal Process (ARP), 512-S Facility (U), G-FDDS-00004, Rev 2, Westinghouse Savannah River Company, August 2003.

\subsection{Engineering Calculations}

a) S. J. Nathan, 512-6S Sampler Shielding, N-CLC-S-00087, Rev 0, WSMS, August 14, 2003.

b) S. J. Nathan, 512-S Backpulse Tank Vault Shielding, N-CLC-S-00080, Rev 0, WSMS, May 19, 2003.

c) S. J. Nathan, 512-S Cell Shielding, N-CLC-S-00081, Rev 0, WSMS, April 30, 2003.

d) S. J. Nathan, Review of Low Point Pump Pit Shielding, WSMS-CRT-03-0031, WSMS, April 8, 2003.

e) S. J. Nathan, 512-S Failed Crossflow Filter Evaluation, N-CLC-S-00085, Rev 0, WSMS, July 9, 2003.

f) S. J. Nathan, 512-S Airborne Activity, N-CLC-S-00082, Rev A, WSMS, April 14, 2003.

g) J. Willison, Determination of Maintenance Condition Dose Rates for Actinide Removal Process, N-CLC-S-00086, Rev 0, WSMS, July 16, 2003.

h) M. D. Drumm, Radiological Inventory of the Actinide Removal Process for the Consolidated Hazards Assessment Process, X-CLC-S-00126, Westinghouse Savannah River Company, Rev 0, April 11, 2003.

\subsection{Codes, Orders, and Standards}

\subsubsection{Code of Federal Regulations}

a) 10CFR835, Occupational Radiation Protection.

\subsubsection{DOE Orders, Standards, Guides, and Handbooks}

a) U.S. Department of Energy, Facility Safety, DOE Order 420.1A, Change 2.

b) U.S. Department of Energy, Design Considerations, DOE-HDBK-1132-99.

c) DOE Order 435.1, Radioactive Waste Management.

\subsubsection{SRS Standards}

a) Westinghouse Savannah River Company, SRS Engineering Standards Manual, Standard 01064, Radiological Design Requirements (U), WSRC-TM-95-1.

b) Westinghouse Savannah River Company, Radiological Control, WSRC 5Q.

c) Westinghouse Savannah River Company, SRS Engineering Standards Manual, Standard 07270, Installation and Inspection of Penetration Seals (U), WSRC-TM-95-1. 
WSRC-TR-2003-00167

REVISION 0

d) Westinghouse Savannah River Company, SRS Engineering Standards Manual, Standard 15889, Confinement Ventilation Systems Design Criteria, WSRC-TM-95-1.

\subsection{Engineering Drawings}

a) Westinghouse Savannah River Company, Savannah River Site 200S-Area, Defense Waste Processing Facility, Late Wash Facility, Radiation Zone Drawing, A-AD-S-0002, Rev 0, June 13, 1996.

\subsection{Supplier Specifications and Documents}

\subsection{Other}

a) J. W. French, Submittal of DWPF TSR Revision 28 and DWPF DSA Revision 21 to DOE for Review and Approval, CBU-WSD-2003-00027, July 28, 2003. [One attachment was Revision 21 of WSRC-SA-6 (DWPF DSA).]

b) Westinghouse Savannah River Company, Waste Management Programs - DWPF, Manual SW4-20.

c) M. G. Hogue, Radiation Monitors for Backpulse Tank Upset Condition Mitigation, U-PMT-S-01339, Westinghouse Savannah River Company, July 23, 2003. 


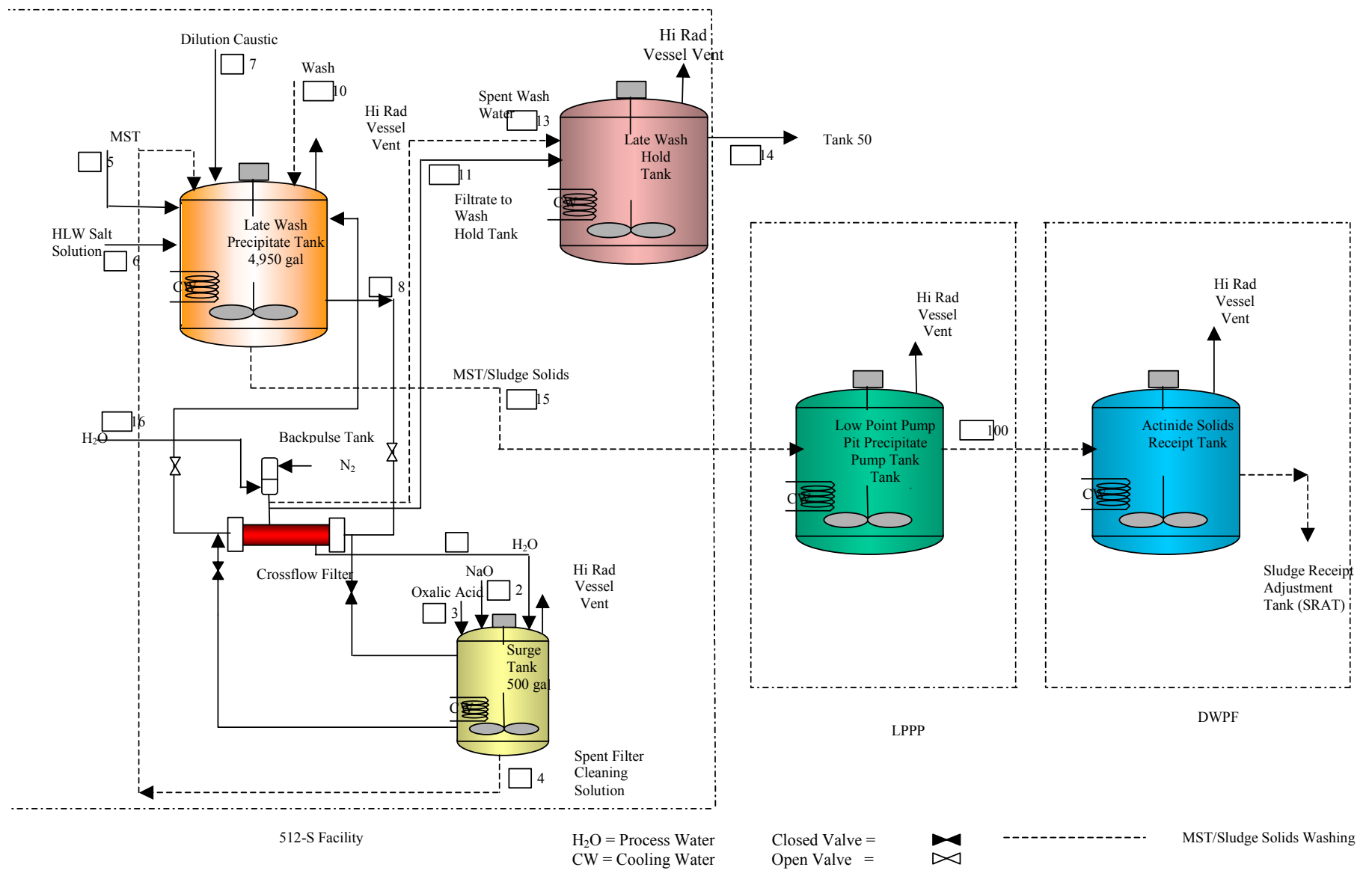

Figure 1 Actinide Removal Process 


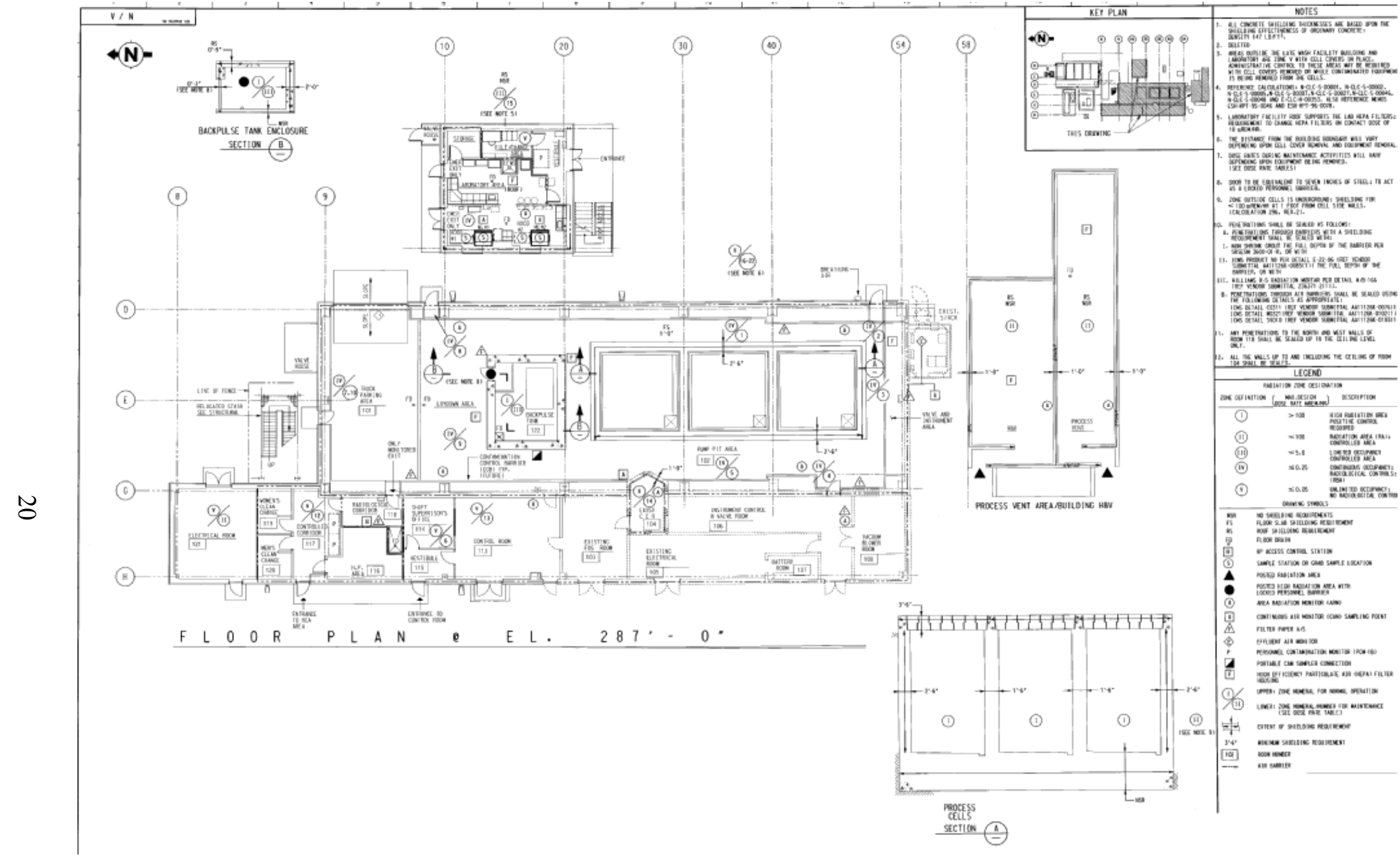

Figure 2 Radiation Zone Diagram 


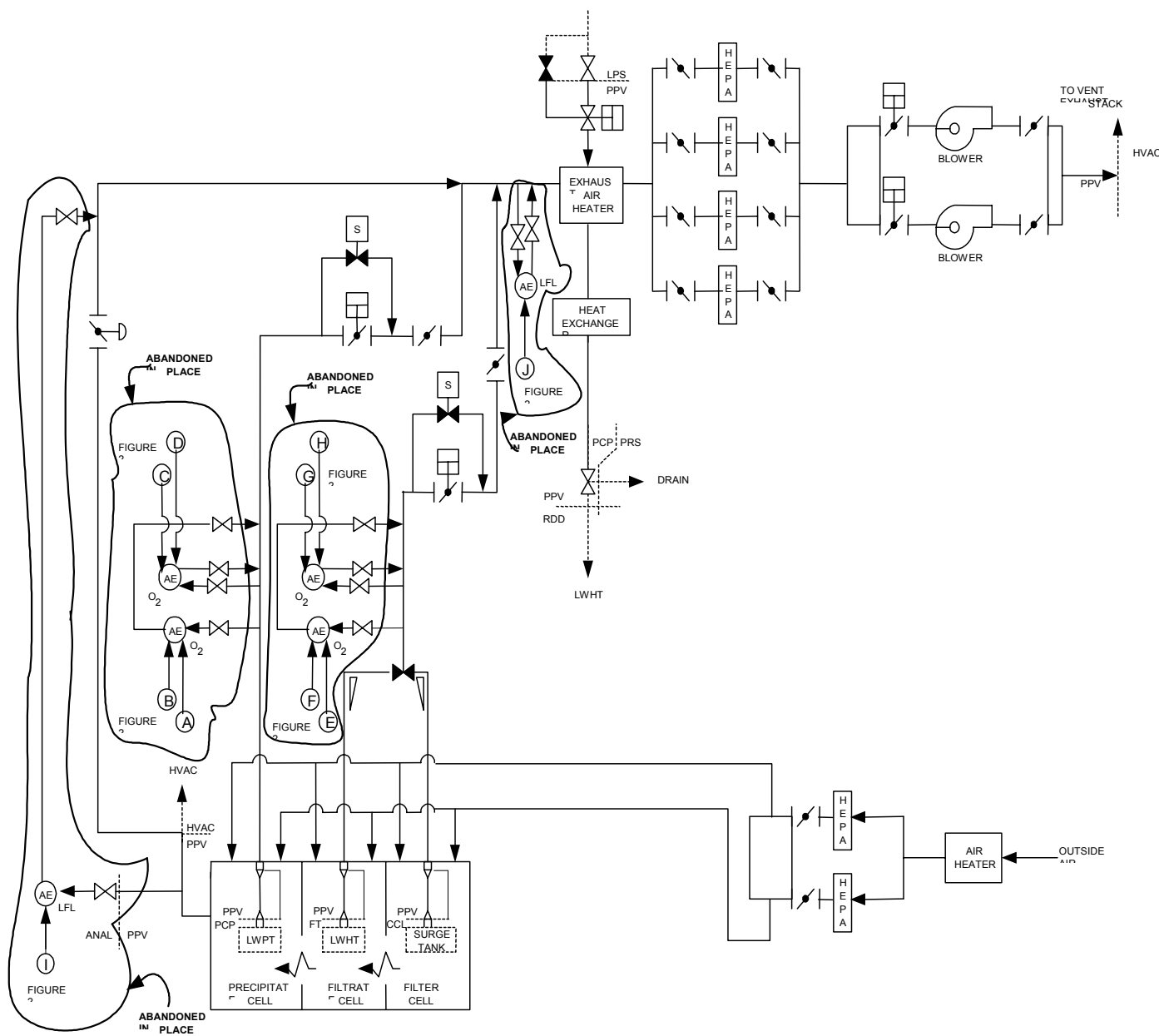

Figure 3 ARP Process Vessel Ventilation System

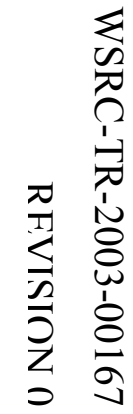


WSRC-TR-2003-00167

REVISION 0

APPENDIX A 
WSRC-TR-2003-00167

REVISION 0

\section{Attachment 1- Calculation Input Document (page 1 of 2)}

\section{Assumption:}

Fouling of the cross-flow filter during operation of the Actinide Removal Process will be bounded by a condition of filling one-third of all the pores to one-third of the pore depth with sludge/monosodium titanate solids.

\section{Justification:}

The current source term for a failed cross-flow filter Building 512-S derives from a blend of experimental data, using tetraphenylborate slurries, and of best engineering judgement from knowledgeable experts who formed a consensus opinion on a conservative case assumption for solids and liquid retention. Prior experimental data indicate no cases in which the cleaning procedure with oxalic acid and caustic proved unable to remove all axial solids from a failed filter. Based upon limited chemical analyses of acid rinses of filters and on destructive analysis of a severely fouled filter element, the expert panel felt justified in offering the assumption of "one third of all pores filled one-third of the depth with a $50 \mathrm{wt} \%$ tetraphenylborate slurry".

For the present application, the tetraphenylborate slurry is replaced by a slurry containing metal hydroxide sludge with added monosodium titanate (MST). The exact ratio of the components remains unknown until operations begin but current design bases assumes a nearly equal mass of each solids. Cleaning of filters fouled with either solids appears comparable to superior to results obtained for tetraphenylborate solids based upon extensive testing with actual and simulated wastes. Since neither solid will retain cesium to any appreciable extent, the amount of retained cesium will prove markedly lower for the present application. Personnel might derive an appropriate source term by blending the values from sludges in SRS tank cleaning efforts along with the actinide content of the MST.

The solids will likely pack to densities far below the $50 \mathrm{wt} \%$ assumption, since the sludge solids are far more rigid and incompressible than the organic solids. A more rational range of concentrations would approximate those observed in sludge tanks [e.g., 15 to $20 \mathrm{wt} \%$ ].

No reliable data could be located on drainage of interstitial liquid from sludge, but it seems likely that it will drain faster and to lower final water content than the tetraphenylborate solids.

For all these reasons, it is judged that the current assumptions on source term for a failed filter grossly conservative from expected operations conditions.

Approvals:

S.D.Fuk

Technical Reviewer

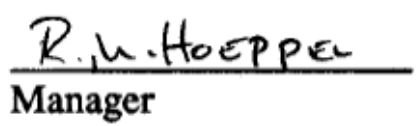

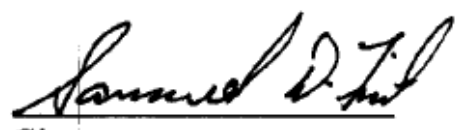

Signature

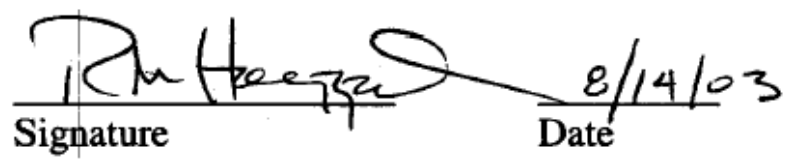


WSRC-TR-2003-00167

REVISION 0

Attachment 1 - Calculation Input Document (page 2 of 2)

\section{References:}

HLW-ITP-940042, A. C. Smith, Revision 2 to Recommendation for ITP Filter Source Strength Following Decontamination, Jan. 18, 1994.

WER-ITP-931289, A. C. Smith, B. G. Crowley, J. N. Brooke, Recommended Source Strength for Cleaned Filter, Oct. 7, 1993.

WER-ITP-930048, Failed Filter Source Strength Design Basis, Feb. 17, 1993. 